\title{
THE CHRONIC MENTAL HOSPITAL POPULATION: A SIX-YEAR FOLLOW-UP STUDY
}

\author{
ANTHEA M. HAILEY \\ MRC Social Psychiatry Unit, Institute of Psychiatry, De Crespigny Park, London SE5
}

The number of chronic long-stay patients in mental hospitals in England and Wales is decreasing year by year. There are two components in this decrease-the decline of an original group over time, and the rate at which 'new' long-stay patients are still accumulating in hospital. The significance of each of these, in the overall decline, is still a topic for discussion and argument. The Hospital Plan of 1962 (Ministry of Health, 1962) had introduced some fundamental changes in the approach to hospital care of the mentally ill; units for psychiatric patients were to be set up in local general hospitals with a view eventually to closing down the old mental hospitals. These latter would no longer be needed once the standing long-stay population had left, through discharge or death. This was expected to happen within about 10 years (Tooth and Brooke, 1961). A study based on the Camberwell area of London for the period 1964-70 was designed to examine many aspects of long-term care; the findings reported here concern the 'old' long-stay population.

\section{Camberwell and the Camberwell Register}

Camberwell is a residential suburb in south London with a population of 170,000 . It is a fairly stable residential area composed of predominantly upper working and lower middle class people (Wing and Hailey, 1972). This study was initially based on the Camberwell Psychiatric Case Register, which monitors all specialist psychiatric care provided for the population of the area.

The Register was based on an initial census of psychiatric patients in care on 31 December 1964 (Wing, Bramley, Hailey, and Wing, 1968). This included all inpatients admitted from Camberwell and all those in a spell of outpatient care with a current Camberwell address. A small amount of social and clinical material was collected for each patient and recorded systematically for computer storage. For inpatients, the date of admission to hospital before the census day was recorded; for outpatients, the dates of attendance before and after the census day which qualified the patient for the Register. From January 1965 onwards, new patients have been added to the Register as they begin to attend the psychiatric services. Once a patient is on the Register all dates of admission, discharge, outpatient attendance, and other forms of contact with services are recorded, so long as he remains a Camberwell resident (Hailey, 1973). Confidentiality is strict; the names of patients are never divulged, and the data are used for research purposes only.

\section{DEFINITIONS FOR THE STUDY}

A long-stay patient, for the present study, was defined as one who had been in a mental hospital continuously for one year or more. If a patient was transferred direct from one psychiatric hospital to another, this whole period was treated as a single inpatient episode; length of stay was measured from the original admission. This criterion was adopted in order that the statistics should be focussed on the individual patient rather than on administrative data. In studying the documents for long-stay patients, it had become evident that in London the transfer of a patient from one mental hospital to another was not uncommon. There were various reasons for this. During the war some mental hospitals were evacuated and given over to military use, for example; in more recent years, a patient might spend a few months at the Maudsley Hospital and then be transferred to Cane Hill or another of the big London mental hospitals. The author was concerned to examine the patient's experience of continuous inpatient care. Patients were included in the study if they had had a Camberwell address on admission to hospital. In order to check the original Register census of 31 December 1964, the author carried out a survey of the original committal papers at each of the mental hospitals for all patients who seemed to meet the criteria for inclusion. Some problems with the coding of addresses, and the designation of patients admitted from the old workhouse as 'Camberwell' patients or not, were found and dealt with. An original Register group of 416 patients was reduced by this means to a group of 
410 who met the stricter criteria for the study. This corresponds to 237 per 100,000 total population. The national rate in 1963 was 213 per 100,000 (Brooke, 1967); more patients from Camberwell had been located than would have been expected.

This paper centres on two aspects of the studythe future of the 1964 population and the fate of long-stay patients on discharge. Detailed results on accumulation of new patients will be given elsewhere.

\section{The Chronic Population In 1964}

The group to be studied comprised all Camberwell patients in mental hospitals on 31 December 1964, who had been in hospital continuously for one year or more.

Patients from Camberwell were found at seven of the 10 mental hospitals which in 1964 served the old London County Council area, and at three other hospitals. Some of them had been in hospital for very many years. A survey of the original committal papers for these patients illustrated the historical development of services in London and the changes in admission procedure during the period over which the group had accumulated. This was an interesting exercise; it is the historical context which has determined the size and characteristics of the present inpatient population.

The earliest admission of a patient in the study was 1895 . Until 1930 all admissions were compulsory. Most patients were certified as 'pauper lunatics' at the local workhouse; the majority of people with severe mental illness found their way there, unless they could afford to pay for private treatment; very few from Camberwell could. Ten asylums were run by the London County Council and patients were admitted to whichever seemed convenient; hence the distribution of Camberwell patients over several hospitals.

The LCC ceased to be the hospital authority in 1948, when all hospitals including the mental hospitals were absorbed into the National Health Service and administered under Regional Hospital Boards. The reference to 'rate aided' disappeared from the committal papers as payment to the hospital was no longer a local responsibility. Catchment areas were devised; Camberwell became part of the catchment area of Cane Hill Hospital. The majority of study patients admitted within about 15 years of the census day were at Cane Hill.

The period 1948-59 was one of development and change; informal admission to hospital became more common. The Mental Health Act of 1959 constituted a complete revision of the laws relating to treatment of mental illness; long-stay Camberwell patients in 1964 who had been admitted comparatively recently were almost all voluntary patients at admission.

The 410 Camberwell patients who had been in hospital one year or more on 31 December 1964 are described in Table I by sex, age, and diagnosis. There were more females than males in eacho diagnostic group, the excess being particularly marked for dementia; overall, $65 \%$ were female and $35 \%$ male. Almost half the patients were aged 65 years or over on the census day. Schizophrenia was the largest diagnostic group, accounting for $75.5 \%$ of male and $48.7 \%$ of female patients. Severe depression, dementia, and neurosis were mostly female disorders. The last group, 'others', consisted of patients with paranoid states (not included in the 'schizophrenia' group), organic dementias, and

TABLE I

PATIENTS IN HOSPITAL ONE YEAK OR MORE ON 31 DECEMBER 1964 ACCORDING TO AGE, SEX AND DIAGNOSIS

\begin{tabular}{|c|c|c|c|c|c|c|c|c|c|c|}
\hline \multirow{2}{*}{\multicolumn{2}{|c|}{ Diagnosis }} & \multirow[b]{2}{*}{ Sex } & \multicolumn{7}{|c|}{ Age (years) } & \multirow[b]{2}{*}{ Total } \\
\hline & & & $15-24$ & $25-34$ & $35-44$ & $45-54$ & $55-64$ & $65-74$ & 75 and over & \\
\hline Schizophrenia & .. & $\mathbf{M}$ & $\begin{array}{l}1 \\
1\end{array}$ & $\begin{array}{l}6 \\
6 \\
\end{array}$ & $\begin{array}{l}12 \\
15\end{array}$ & $\begin{array}{l}28 \\
20\end{array}$ & $\begin{array}{l}31 \\
38\end{array}$ & $\begin{array}{l}20 \\
27\end{array}$ & $\begin{array}{l}10 \\
23\end{array}$ & $\begin{array}{l}108 \\
130\end{array}$ \\
\hline $\begin{array}{l}\text { Severe } \\
\text { depression }\end{array}$ & . & $\mathbf{M}$ & = & $=$ & $=$ & -6 & $\begin{array}{r}1 \\
10\end{array}$ & $\overline{11}$ & $\begin{array}{r}3 \\
20\end{array}$ & $\begin{array}{r}4 \\
47\end{array}$ \\
\hline Dementia & .. & $\begin{array}{l}\mathbf{M} \\
\mathbf{F}\end{array}$ & $=$ & 二 & 二 & $=$ & 3 & $\begin{array}{l}1 \\
8\end{array}$ & $\begin{array}{r}3 \\
33\end{array}$ & $\begin{array}{r}7 \\
41 \\
\end{array}$ \\
\hline Neurosis & .. & $\mathbf{M}$ & $=$ & 1 & $\overline{1}$ & $\overline{1}$ & $\overline{3}$ & $\overline{3}$ & $\overline{5}$ & 13 \\
\hline Others .. & .. & $\begin{array}{l}\mathbf{M} \\
\mathbf{F}\end{array}$ & $\overline{1}$ & $\begin{array}{l}1 \\
1\end{array}$ & 4 & $\begin{array}{l}2 \\
5 \\
\end{array}$ & $\begin{array}{r}5 \\
12\end{array}$ & $\begin{array}{l}8 \\
6\end{array}$ & ${ }_{11}^{3}$ & $\begin{array}{l}23 \\
36\end{array}$ \\
\hline \multirow[t]{2}{*}{ Total .. } & . & $\mathbf{M}$ & $\begin{array}{l}1 \\
2\end{array}$ & $\begin{array}{l}8 \\
7 \\
\end{array}$ & $\begin{array}{l}16 \\
16\end{array}$ & $\begin{array}{l}30 \\
32\end{array}$ & $\begin{array}{l}40 \\
63\end{array}$ & $\begin{array}{l}29 \\
55 \\
\end{array}$ & $\begin{array}{l}19 \\
92 \\
\end{array}$ & $\begin{array}{l}143 \\
267\end{array}$ \\
\hline & & M \& F & 3 & 15 & 32 & 62 & 103 & 84 & 111 & 410 \\
\hline
\end{tabular}


personality disorders. It also included 27 patients with a primary diagnosis of mental deficiency or epilepsy. This confirmed that, in the past, and particularly before the establishment of separate hospitals for subnormality and psychiatric illness in 1913, the classification and 'disposal' of patients differed from the present day. (Some patients in the study had been transferred to a mental hospital from the LCC epileptic colony-St. Ebba's-or another hospital which is now part of the subnormality services).

Table II shows length of stay on the census day. More than half the patients had been continuously in hospital for 15 years or more, that is, since before the inception of the National Health Service. For males, the median length of stay was longer than for females, 23.4 years and 13.5 years respectively. An analysis by diagnosis showed that most of the patients with a stay of 15 years or more were diagnosed schizophrenic; indeed, all except 12 of the 95 males with this length of stay were schizophrenics.

In Table III we compare the age of the patient at admission to hospital with his or her age on the study census day. This enables us to examine the number of patients who had grown old in the mental hospital. Of the 195 patients aged 65 or over in 1964, who may be considered the geriatric mental hospital population, $115(59.0 \%)$ had been admitted before reaching that age; 38 of these patients had been admitted to hospital before the age of 35 .

\section{ThOSE WHO LEFT Hospital 1965-70}

The whole group of patients was followed for six years to 31 December 1970, in order to discover the rate at which this population was being reduced each year by death and discharge. Table IV shows the numbers and proportions of the group who died or were discharged over the period. (Four patients who were transferred direct to another mental hospital are not included here.) The death rate was about three times the discharge rate, reflecting the

\section{TABLE IV}

PATIENTS IN HOSPITAL ONE YEAR OR MORE ON 31 DECEMBER 1964: DISCHARGES AND DEATHS, 1965-70

\begin{tabular}{|c|c|c|c|c|c|c|}
\hline \multirow[t]{2}{*}{$(n=410)$} & \multicolumn{2}{|c|}{ Discharged } & \multicolumn{2}{|c|}{ Died } & \multicolumn{2}{|c|}{ Remained 31 Dec } \\
\hline & No. & $\%$ & No. & $\%$ & No. & $\%$ \\
\hline $\begin{array}{l}1965 \\
1966 \\
1967 \\
1968 \\
1969 \\
1970\end{array}$ & $\begin{array}{r}10 \\
11 \\
7 \\
3 \\
7 \\
4\end{array}$ & $\begin{array}{l}2.4 \\
2.7 \\
1.7 \\
0.7 \\
1.7 \\
1.0\end{array}$ & $\begin{array}{l}30 \\
29 \\
28 \\
17 \\
18 \\
15\end{array}$ & $\begin{array}{l}7 \cdot 3 \\
7 \cdot 1 \\
6 \cdot 8 \\
4 \cdot 1 \\
4 \cdot 4 \\
3 \cdot 7\end{array}$ & $\begin{array}{l}370 \\
330 \\
295 \\
275 \\
250 \\
231\end{array}$ & $\begin{array}{l}90 \cdot 3 \\
80 \cdot 5 \\
72 \cdot 0 \\
67 \cdot 1 \\
61 \cdot 0 \\
56 \cdot 3\end{array}$ \\
\hline
\end{tabular}

TABLE II

PATIENTS IN HOSPITAL ONE YEAR OR MORE ON 31 DECEMBER 1964 ACCORDING TO SEX AND LENGTH OF STAY

\begin{tabular}{|c|c|c|c|c|c|c|c|c|}
\hline \multicolumn{3}{|c|}{$\begin{array}{c}\text { Length of Stay } \\
\text { (years) }\end{array}$} & Males & $\%$ Cum. & Females & $\%$ Cum. & Total & $\%$ Cum. \\
\hline $\begin{array}{ll}1- & \cdots \\
2- & \cdots \\
3- & \cdots \\
5- & \cdots \\
10- & \cdots \\
15- & \cdots \\
20- & \cdots \\
25- & \cdots \\
35- & \cdots \\
45 \text { or more }\end{array}$ & $\begin{array}{l}\ldots \\
\ldots \\
\ldots \\
\ldots \\
\ldots \\
\cdots \\
\ldots\end{array}$ & $\begin{array}{l}\ldots \\
\cdots \\
\cdots \\
\cdots \\
\cdots \\
\cdots \\
\cdots\end{array}$ & $\begin{array}{l}5 \\
8 \\
8 \\
13 \\
14 \\
12 \\
17 \\
32 \\
24 \\
10\end{array}$ & $\begin{array}{r}3 \cdot 5 \\
9 \cdot 1 \\
14 \cdot 7 \\
23 \cdot 8 \\
33 \cdot 6 \\
42 \cdot 0 \\
53 \cdot 9 \\
76 \cdot 3 \\
93 \cdot 1 \\
100 \cdot 0\end{array}$ & $\begin{array}{l}33 \\
23 \\
21 \\
37 \\
28 \\
24 \\
14 \\
37 \\
30 \\
20\end{array}$ & $\begin{array}{r}12 \cdot 3 \\
20 \cdot 9 \\
28 \cdot 8 \\
42 \cdot 6 \\
53 \cdot 1 \\
62 \cdot 1 \\
67 \cdot 3 \\
81 \cdot 2 \\
92 \cdot 4 \\
100 \cdot 0\end{array}$ & $\begin{array}{l}38 \\
31 \\
29 \\
50 \\
42 \\
36 \\
31 \\
69 \\
54 \\
30\end{array}$ & $\begin{array}{r}9 \cdot 3 \\
16 \cdot 8 \\
23 \cdot 9 \\
36 \cdot 1 \\
46 \cdot 4 \\
55 \cdot 1 \\
62 \cdot 7 \\
79 \cdot 5 \\
92 \cdot 7 \\
100 \cdot 0\end{array}$ \\
\hline Total & . & .. & 143 & & 267 & & 410 & \\
\hline
\end{tabular}

TABLE III

PATIENTS IN HOSPITAL ONE YEAR OR MORE ON 31 DECEMBER 1964 ACCORDING TO AGE AT ADMISSION AND AGE ON THAT DAY

\begin{tabular}{|c|c|c|c|c|c|c|c|c|c|c|}
\hline \multirow{2}{*}{\multicolumn{3}{|c|}{$\begin{array}{c}\text { Age on } \\
31 \text { December } 1964\end{array}$}} & \multicolumn{7}{|c|}{ Admission Age (years) } & \multirow[b]{2}{*}{ Total } \\
\hline & & & Less than 25 & $25-34$ & $35-44$ & $45-54$ & $55-64$ & $65-74$ & 75 and over & \\
\hline $\begin{array}{l}15-24 \\
25-34 \\
35-44 \\
45-54 \\
55-64 \\
65-74 \\
75 \text { and over }\end{array}$ & $\begin{array}{l}\cdots \\
\cdots \\
\cdots \\
\cdots\end{array}$ & $\begin{array}{l}\cdots \\
\cdots \\
\cdots \\
\cdots \\
\cdots\end{array}$ & $\begin{array}{r}3 \\
10 \\
11 \\
16 \\
24 \\
7 \\
2\end{array}$ & $\begin{array}{r}5 \\
13 \\
20 \\
26 \\
18 \\
11\end{array}$ & $\begin{array}{r}8 \\
15 \\
15 \\
21 \\
10\end{array}$ & $\begin{array}{l}11 \\
26 \\
13 \\
13\end{array}$ & $\begin{array}{l}12 \\
10 \\
10\end{array}$ & $\begin{array}{l}15 \\
34\end{array}$ & 31 & $\begin{array}{r}3 \\
15 \\
32 \\
62 \\
103 \\
84 \\
111\end{array}$ \\
\hline Total & . & . & 73 & 93 & 69 & 63 & 32 & 49 & 31 & 410 \\
\hline
\end{tabular}


age characteristics of the group. The numbers leaving hospital were slackening over time; the reduction over the period 1965-70 was more curved than linear (see Tooth and Brooke, 1961; Norton, 1961 ; Kingston, 1962; Lindsay, 1962; Baldwin and Hall, 1967; Hailey, 1971).

The 137 deaths in hospital occurred throughout the range of length of stay; all except 35 were of people aged 65 years or over. Discharges were much more common in the shorter stay groups, as one would expect. After six years, $56 \%$ of the Camberwell cohort were still in hospital, $10 \%$ had been discharged, and the rest had died in hospital.

(A continuation of the statistical analysis to 1971 and 1972 shows an increase in discharges during these years. Some 20 patients left hospital, and a further 25 died in hospital. There were 186 of the original group still in hospital on 31 December 1972 , eight years after the original census.)

\section{The Discharged Patients}

The interpretation of discharge statistics for longstay patients is hazardous without some indication of the destination of patients on discharge and knowledge of whether they remained in the community or were soon readmitted to hospital. A high rate of discharge of long-term patients does not necessarily indicate a 'successful' mental health service; it may indicate quite the reverse.

The $10 \%$ of Camberwell patients who were discharged before the end of the six-year follow-up period (42 patients) were each traced back into the community in order to discover where they had gone from the mental hospital and whether they were readmitted within 12 months. An attempt was also made to relocate each of these 42 patients at the end of the period.
The Camberwell Register gave information on further psychiatric care for those who returned to a Camberwell address on discharge $(55 \%$ of the group). For the rest, four main sources of information were used. The hospital case notes gave some data; information could also be obtained from other institutions, such as old people's homes, where the patient had been living. The NHS Central Register kindly checked a number of patients for death notification; the Department of Health and Social Security Mental Health Enquiry gave data on readmissions of a few patients now living outside Camberwell.

Table $\mathrm{V}$ divides these discharged patients into three broad groups. The first consists of eight patients who went direct to a general hospital because of physical illness. Six of them died there and had been discharged only because death was imminent; the other two returned to the mental hospital after treatment. Thus these were not 'real' discharges at all. The second group was those who went to longterm care in other institutions, either to old people's homes or to long-term hostels for the mentally ill. The one female patient who was formally discharged, but remained at the hospital as a resident domestic was included in this group. One of these patient died within a few months of discharge.

The third group was composed of those who wen to live with family or friends, or to a short-term hostel, or to live alone. These 29 are the only patients who were discharged to non-institutional home surroundings.

The data are given by sex, age, and diagnosis. None of the elderly patients settled in a non-institutional setting for long. There were no striking differences between schizophrenia and other diagnoses. Only about one third of the patients (15 out of 42) remained out of hospital or other institutions for 12 months.

TABLE V

PATIENTS IN HOSPITAL ONE YEAR OR MORE ON 31 DECEMBER 1964 WHO WERE DISCHARGED FROM HOSPITAL DURING 1965-70, ACCORDING TO SEX, AGE ON THAT DAY, DIAGNOSIS, AND PLACE TO WHICH DISCHARGED

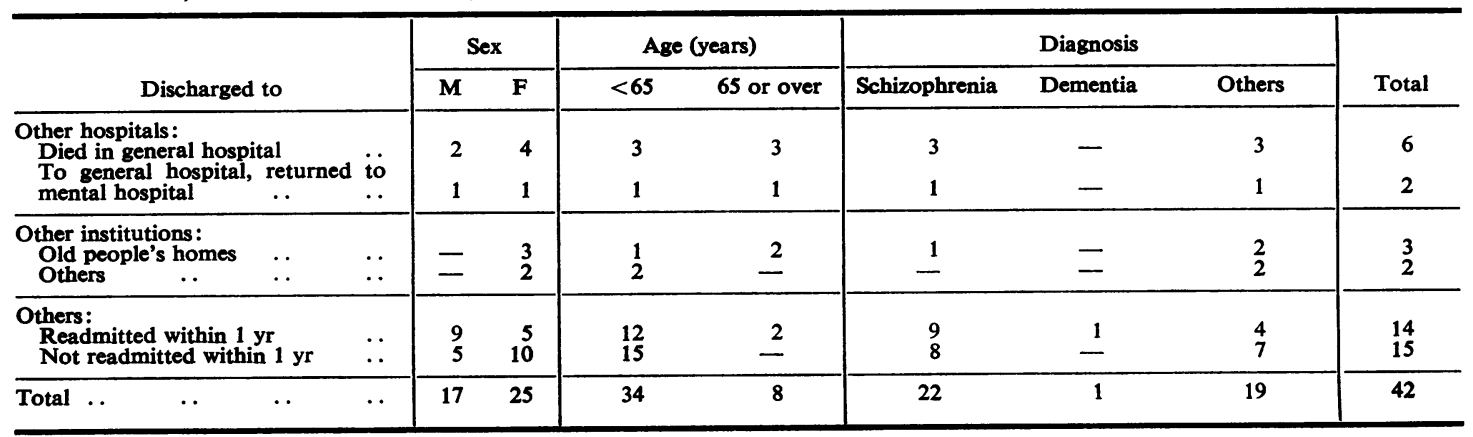


TABLE VI

PATIENTS IN HOSPITAL ONE YEAR OR MORE ON 31 DECEMBER 1964 WHO DIED OR WERE DISCHARGED DURING 1965-70

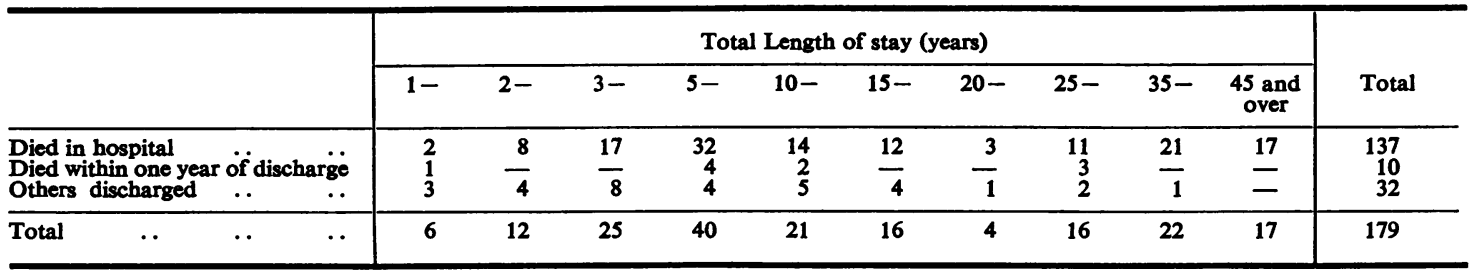

We may compare these findings with those of Brown, Carstairs, and Topping (1958) and Brown (1959), who reported on a group of male patients aged 65 years or less discharged in 1949-56 after more than two years in a mental hospital. They found that $68 \%$ remained out of hospital for a year. If we exclude, as Brown did, those patients who died within a year of discharge and those aged over 65, we obtain a group of Camberwell patients fairly comparable with his, except for the inclusion of females. The proportion from Camberwell who remained out of hospital for a year or more was $59 \%$ (17 out of 29 patients). There is a difference of 20 years between the beginning of Brown's study and the end of the Camberwell study; the fate of longstay mental patients discharged into the community seems to have changed very little over this period.

\section{The Whole Group Six Years Later}

The final length of stay of those patients who left hospital during the six years is shown in Table VI. Those who died included some shorter stay patients but were distributed throughout the range of length of stay; 49 died after 25 years or more as mental hospital inpatients. More than one third of those discharged had been in hospital 10 years or more by the time they left.

The follow-up study of the whole of the 1964 group to the end of the six-year period enables us to consider the extent to which those discharged from the mental hospital after an extended stay were able to cope with life outside. An attempt was made to trace every patient's whereabouts on 31 December 1970 . Some $3 \%$ of the cohort, 11 patients, could not be located.

Table VII gives the results of the study. Apart from the 11, some of whom might quite possibly have drifted into the prison population or be living an unsettled life in hostels or lodgings, only three others were in the community other than in institutions at the end of six years. Eleven patients were back in hospital; four of these had been there a year or more by December 1970.
TABLE VII

PATIENTS IN HOSPITAL ONE YEAR OR MORE ON 31 DECEMBER 1964 ACCORDING TO OUTCOME BY 31 DECEMBER 1970

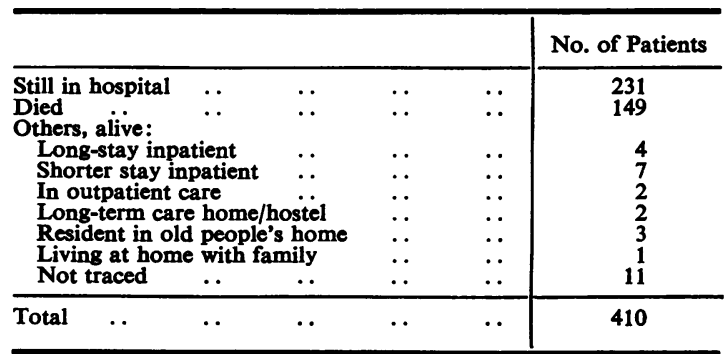

\section{CONCLUSIONS}

Tooth and Brooke (1961) concluded from their statistical analysis that all the long-stay patients in 1954 would have left hospital within 16 years, i.e., by about 1970 . These were patients with a stay of two years or more, that is, they were admitted in 1952 or before. From Camberwell alone, there were still 164 patients in hospital on 31 December 1970 with a length of stay of 20 years or more. Thus the predictions of Tooth and Brooke have not been fulfilled.

Of the original 1964 group of 410 Camberwell patients, 231 were still in hospital six years later, at the end of 1970. The age distribution of these patients is shown in Table VIII. Many of these are

TABLE VIII

PATIENTS IN HOSPITAL ONE YEAR OR MORE ON 31 DECEMBER 1964 WHO WERE STILL IN HOSPITAL AT THE END OF 1970 ACCORDING TO AGE

\begin{tabular}{|c|c|c|}
\hline $\begin{array}{c}\text { Age on } \\
31 \text { December } 1970 \\
\text { (years) }\end{array}$ & No. of Patients & Percentage \\
\hline $\begin{array}{l}\text { Less than } 45 \\
45-54 \quad \ldots \\
55-64 \quad \ldots \\
65-74 \quad \ldots \\
75 \text { and over }\end{array}$ & $\begin{array}{l}17 \\
34 \\
60 \\
55 \\
65\end{array}$ & $\begin{array}{r}7 \cdot 4 \\
14 \cdot 7 \\
26 \cdot 0 \\
23 \cdot 8 \\
28 \cdot 1\end{array}$ \\
\hline Total & 231 & $100 \cdot 0$ \\
\hline
\end{tabular}


unlikely to die in the near future; up to about a hundred could still be in hospital in 10 years' time, in the absence of any alternative provision.

It is still official policy to work towards the eventual closure of the large separate mental hospitals (Department of Health and Social Security, 1971), although it is now recognized that this will not be feasible in the very near future. The DHSS memorandum "Services for mental illness related to old age" (DHSS, 1972) deals with patients who have grown old in mental hospitals as a special group. Regular re-assessment is essential for these patients, and 'care should be taken to transfer patients, wherever possible, with the staff to whom they are accustomed and to an environment similar to that which they have left'. The question becomes one of providing appropriate and adequate alternatives for both elderly chronic patients and those who are not yet old but have been in hospital for many years.

\section{REFERENCES}

BALDWIN, J. A. and HALl, D. J. (1967). Estimation of the outcome of a standing mental hospital population. Brit. J. prev. soc. Med., 21, 56.

BroOKE, E. M. (1967). A census of patients in psychiatric beds, 1963. Ministry of Health: Reports on Public Health and Medical Subjects, No. 116. HMSO, London.

Brown, G. W. (1959). Experiences of discharged chronic schizophrenic patients in various types of living group. Milbank mem. Fd Quart., 37, 105.

-, Carstairs, G. M., and Topping, G. (1958). Posthospital adjustment of chronic mental patients. Lancet, 2,685 .
Department of Health and Social Security (1971). Hospital Services for the Mentally Ill. A Memorandum. HMSO, London.

(1972). Services for Mental Illness Related to Old Age. A Memorandum. HMSO, London.

HAILEY, A. M. (1971). Long-stay psychiatric inpatients: a study based on the Camberwell Register. Psychol. Med., 1, 128.

- (1973). The Camberwell Register. Paper presented ळ at Psychiatric Case Registers Conference, Aberdeen, $\vec{\circ}$ March 1973. To be published.

KINGSTON, F. E. (1962). Trends in mental-hospital population and their effect on planning. Letter in Lancet, $2,49$.

LINDSAY, J. S. B. (1962). Trends in mental-hospital iv population and their effect on planning. Letter in is Lancet, 1, 1354.

Ministry of Health: National Health Service (1962). A hospital plan for England and Wales. Cmnd. 1604. HMSO, London.

NorTON, A. (1961). Needs and beds. Letter in Lancet, $1,884$.

Tooth, G. C. and Brooke, E. M. (1961). Trends in the mental hospital population and their effect on futures planning. Lancet, 1, 710.

WiNG, J. K. and Hailey, A. M. (eds). (1972). Evaluating a Community Psychiatric Service. Published by the Oxford University Press for Nuffield Provincial Hospitals Trust, London.

Wing, L., Bramley, C., Hailey, A., and Wing, J. K. (1968). Camberwell cumulative psychiatric case Register. Part 1: Aims and methods. Soc. Psychiat., 3, 116 .

\section{CORRECTION}

In the August issue of the journal, the authors of the paper on p.168, 'New Haven Survey of Joint Diseases XVI. Impairment, Disability, and Arthritis', are Roy M. Acheson, Jennifer L. Kelsey, and Gerald N. Ginsburg. 